11. Tadeieva M. I. Rozvytok suchasnoi shkilnoi inshomovnoi osvity v kra-yinakh-chlenakh Rady Yevropy: monohrafiia. [The development of modern school-based foreign language education in the member states of the Council of Europe]. Ternopil: Navchalna knyha Bohdan, 2011. 432 p.

12. Arndt D. Schulpraktische Studien - integrativer Bestandteil im Studiengang «Lehramt an berufsbildenden Schulen» / D. Arndt, F. Bernard, B. Schröder // Lehrerbildung im gesellschaftlichen Wandel. Frankfurtam-Main: Gesellschaft zur Förderung Arbeitsorientierter Forschung und Bildung, 2002. P. 195-220.

13. Bach, G., Timm, J.-P. (Hrsg.): Englischunterricht. Grundlagen und Methoden einer handlungsorientierten Unterrichtspraxis (4., vollst. überarb. u. erweit. Aufl.). Tübingen, Basel: A. Francke Verlag, 2009. 384 p.

14. Borchard Ch. Hochschuldidaktische Weiterbildung - Akzeptanz und Wirkung.Eine Analyse am Beispiel eines Bausteinprogramms WindH - Weiterbildung in der Hochschullehre. Münster: LIT Verlag, 2002. $232 \mathrm{p}$.

15. Bosse D. Zur Situation der Lehrerbildung in Deutschland // Reform der Lehrerbildung in Deutschland, Österreich und der Schweiz. Teil I: Analysen, Perspektiven und Forschung. Immenhausen bei Kassel: Prolog-Verl., 2012. P. 11-23.

16. Demmelhuber W. European educational policy related to academic mobility. Berlin: Mensch-und-BuchVerl., 2003. 239 p.

17. Empfehlungen zur Eignungsabklärung in der ersten Phase der Lehrerausbildung (Beschluss der Kultusministerkonferenz vom 07.03.2013). Available at: https://www.kmk.org/fileadmin/Dateien/veroeffentlichungen_beschluesse/2013/2013-03-07-EmpfehlungEignungsabklaerung.pdf.

18. European Profile for Language teacher education. - A frame of reference. Final Report, 2004. - 124 p.

19. Lehrerbildung heute: Impulse für Studium und Lehre / Hochschulrektorenkonferenz. Projekt nexus // Verantw.: Peter A. Zervakis. Red.: Christina Preusker, Dorothee Fricke, Katja Zierleyn. 1.Aufl. Bonn, 2014. $65 \mathrm{p}$.

20. Neuner G. Germanisten oder Deutschlehrer? Zur curricularen Planung einer wissenschaftlichen Deutschlehrerausbildung // Fremdsprache Deutsch, [Sondernummer]. 1994. P. 12-15.

21. Stamm K.-D. Stichworte von A bis Z: zu Bildung, Jugend und Gesellschaft in der DDR 1949-1990 / Klaus-Dieter Stamm. Norderstedt: Books on Demand, 2013. 172 p.

22. Terhart E. Perspektiven der Lehrerbildung in Deutschland. Abschlussbericht der von der Kultusministerkonferenz eingesetzten Kommission. Weinheim und Basel: Beltz, 2000. 160 p.

23. The training of teachers of a foreign language: Development in Europe. Main Report, 2002. 90 p.

Стаття надійшла в редакиію 22.03.2019 p.

УДК37.011:305

DOI 10.25128/2415-3605.19.1.8

IRYNA SHULHA

ORCID ID 0000-0002-0651-047X

ira.shulha@gmail.com

Candidate of Pedagogical Sciences

Ternopil Volodymyr Hnatiuk National Pedagogical University

2 Maksyma Kryvonosa Str., Ternopil, Ukraine

\title{
THEORETICAL BASIS OF THE ORGANIZATION OF THE GENDER-EQUITABLE ENVIRONMENT IN THE FOREIGN AND UKRAINIAN EDUCATIONAL SYSTEM
}

The article deals with a theoretical and methodological analysis of the organization of a gender-equitable educational environment in the context of foreign and native approaches. The terminology field of the research in the foreign and native scientific literature is determined. The peculiarities of the organization of a genderequitable environment in the USA, Canada, Germany and the Scandinavian countries are characterized. The common and different features in methodological approaches were identified. The conceptual-categorical apparatus of the research ("Gender Equitable Learning Environment", "Gender-balanced Education", "Gender Equality in Education", "Gender-equitable Education", "Gender-fair Education", "Nondiscrimination Education", "Non-sexist Education”, "Human Rights Friendly School”) is given. The progressive ideas of implementation of foreign experience to the native practice organization of a genderequitable educational environment are highlighted. The author's interpretation of the concept "gender-equitable environment", its content and structure (spatial-subject, psychodidactic, social components) are formulated. The gender-equitable environment is creative-developing, health-saving, non-discriminatory and inclusive 
environment for children, which are relevant to the principles of social justice, gender equality, child-centrism, egalitarianism, non-discriminatory education, and "partnership pedagogy", gender "matrix" of humanistic pedagogical heritage. The conceptual model of creating a gender-equitable environment on the basis of the integration of competency, personal oriented and gender approaches in the context of reforming the national education is substantiated. The mechanisms of creating an educational environment for children and youth on the basis of "partnership pedagogy" and gender "matrix" of humanistic pedagogical heritage are described.

Keywords: gender, gender approach, gender-equitable environment, educational institution.

ІРИНА ШУЛЬГА

кандидат педагогічних наук

Тернопільський національний педагогічний університет

імені Володимира Гнатюка

вул. Максима Кривоноса 2, м. Тернопіль, Україна

\title{
ТЕОРЕТИЧНІ ЗАСАДИ ОРГАНІЗАЦІЇ ГЕНДЕРНО-СПРАВЕДЛИВОГО СЕРЕДОВИЩА У ЗАРУБІЖНІЙ ТА УКРАЇНСЬКІЙ ОСВІТНІЙ СИСТЕМІ
}

Представлений теоретико-методологічний аналіз організаиії тендерно-справедливого освітнього середовища в контексті зарубіжних та украӥнській підходів. Визначено термінологічне поле дослідження в зарубіжній та українській літературі. Охарактеризовано особливості організачії гендерно-справедливого середовища у США, Канаді, Німеччині, крайнах Скандинавї, виявлено спільне та відмінне у методологічних підходах до проблеми. Подано понятійно-категоріальний апарат дослідження («тендерно-справедливе освітнє середовище», «тендерно-збалансована освіта», «гендерна рівність в освіті», «тендерно-справедлива освіта», «недискримінаційна освіта», «несексистська освіта», «школа, де поважають права людини»). Виокремлені прогресивні ідеї реалізації зарубіжного досвіду у вітчизняну практику створення гендерно-справедливого освітнього середовища в Україні.

Розкрито авторське розуміння поняття «тендерно-справедливе середовище». Гендерносправедливе середовище розглядається як творчо-розвивальне, здоров'язбережувальне, недискримінаційне, інклюзивне середовище для дітей (з урахуванням їх статі, віку, інвалідності, етнічної приналежності, раси тощо), щуо базується на принципах сочіальної справедливості, тендерної рівності, дитиночентризму, еталітаризму, недискримінаційної освіти. У структурі тендерносправедливого середовища виокремлено три компоненти: просторово-предметний (розташування закладу, інтер 'єр та екстер 'єр, наявність зон відпочинку, тло, на основі якого розгортаються стосунки всіх учасників навчально-виховного процесу); психодидактичний (змістова сфера - навчальні плани $i$ програми, підручники, навчальні посібники, форми, методи і прийоми навчання та виховання, які зумовлені психологічними цүілями побудови освітнього процесу); соціальний (суб'єкти освітнього процесу-вчителі, батьки, учні/учениці; комунікаційна сфера (стиль взаємостосунків педагогічного колективу із учнями та батьками).

Обтрунтовано концептуальну модель створення тендерно-справедливого середовища в умовах реформування національної освіти, на засадах інтеграції компетентнісного, особистісно орієнтованого та тендерного підходів. Описуються механізми створення освітнього середовища для дітей та молоді на засадах «педагогіки партнерства» та тендерної «матриціџ гуманістичної педагогічної спадщини.

Ключові слова: тендер, тендерний підхід, тендерно-справедливе середовище, освітній заклад.

ИРИНА ШУЛЬГА

кандидат педагогических наук

Тернопольский национальный педагогический университет

имени Владимира Гнатюка

ул. Максима Кривоноса 2, г. Тернополь, Украина

\section{ТЕОРЕТИЧЕСКИЕ ОСНОВЫ ОРГАНИЗАЦИИ ГЕНДЕРНО-СПРАВЕДЛИВОЙ СРЕДЫ В ЗАРУБЕЖНОЙ И УКРАИНСКОЙ ОБРАЗОВАТЕЛЬНОЙ СИСТЕМЕ}

\begin{abstract}
Представлен теоретико-методологический анализ организачии гендерно-справедливой образовательной среды в контексте зарубежных и отечественных подходов. Определено терминологическое поле исследования в зарубежной и отечественной литературе. Охарактеризованы особенности организачии гендерно-справедливой среды в США, Канаде, Германии, странах Скандинавии, определены общие и отличительные черты в методологических подходах к проблеме.
\end{abstract}


ГЕНЕЗА ПЕДАГОГІЧНОЇ ДУМКИ ТА ОСВІТНІ СИСТЕМИ ЗА РУБЕЖЕМ

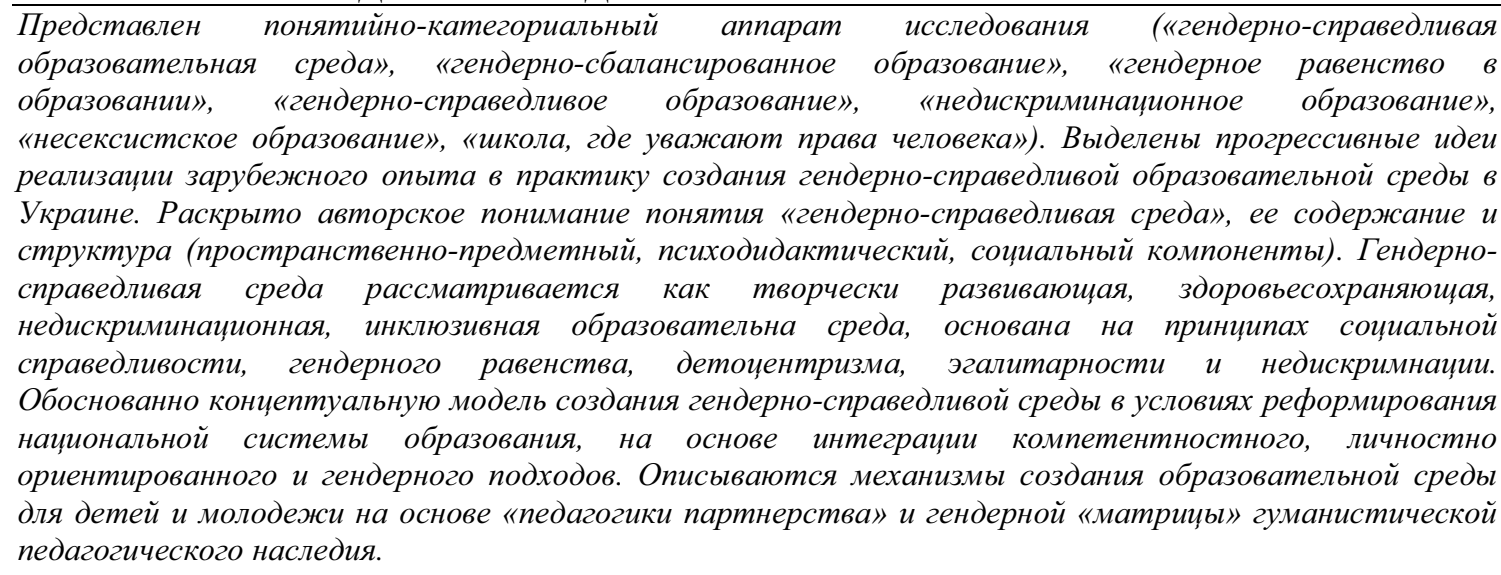

Ключевые слова: гендер, гендерный подход, гендерно-справедливая среда, образовательное учреждение.

The challenge of time and priority task of the state social and humanitarian policy of Ukraine is a democratization of the educational processes, which causes the organization of a gender-equitable environment in educational institutions, relevant to the principles of parity, gender equality; the competent, personal oriented, and gender approaches. This is confirmed by Sustainable Development Goals until 2030, approved by the General Assembly of the United Nations, the Declaration of Millennium Development Goals, Council of Europe Gender equality strategy 2018-2023, National Doctrine of Education Development in the $21^{\text {st }}$ Century, Concept of the New Ukrainian School, Strategy of the Implementation of Gender Equality and Non-Discrimination in Education "Education: Gender Dimension - 2021").

However, the modern stage of development of Ukrainian society is characterized by an ambivalent attitude to gender roles system; the conflict between the old dichotomous their distribution and new, egalitarian, challenges to them. There are strengthening of patriarchal challenges to parity democracy, "gender eclecticism", gender asymmetry in "masculinisation" and "feminization" of student contingent, stereotyping of the public consciousness, etc., which requires finding effective mechanisms for the institutionalization of native gender education, analysis of the concept and categorical apparatus, verification of the experience of conducting gender mainstreaming and antidiscrimination expertise, strengthening the teacher's gender sensitivity to education of equality of both sexes, forming gender competencies as key life competencies of the young generation, because they determine competitiveness on the work market, the ability to establish democratic principles in private and public life.

In this case, the accumulated foreign practical experience and theoretical generalizations on finding effective mechanisms for creating a gender-equitable environment, its contents and structures are especially relevant in the context of reformation of the national education system.

There are a lot of foreign scientific papers which deal with the development and introduction of gender-education techniques, anti-discrimination and anti-bullying practices at school; considerable experience about the organization of the gender-equitable education at school, which ensures the right of all children, taking into account child's age, sex, ethnicity, potential disability, etc. to obtain accessible and quality educational services by them (first of all, the experience of the USA, Canada, United Kingdom, Germany, Sweden, Belgium, Finland and Estonia).

The content of a gender-equitable education, based on gender approach is revealed in foreign studies (S. Bem, S. Bern, L. Eliot, Ph. Jackson, K. Linch, G. Ostrem). The problem of educational sphere transformation is revealed in the research of native scientists: V. Andrushchenko (modernization of higher education), I. Bekh (personal oriented education), L. Hrynevych (educational reforms), V. Kremen (transformation of educational content, transformation of personality), O. Savchenko (reforms in primary education), S. Sysoeva (educational reforms: educational context), O. Sukhomlynska (reformation of the educational component), T. Hovorun, S. Vykhor, V. Haidenko, T. Doronina, O. Kiz, O. Kikinezhdi, O Kostiuk, V. Kravets, O. Masalitina, O. Maruschenko, I. Shulha (implementation of gender approach to educational sphere).

Наукові записки. Серія: педагогіка. - 2019. - № 1. 
At the same time the problem of creating a gender-equitable environment for children at the national school is unresolved issue, which causes the aim of our study - to reveal the theoretical principles of the organization of a gender-equitable environment in foreign educational system and find out ways of their adaptation and implementation to the Ukrainian educational institutions.

Scientists interpret educational environment as a generalized, holistic and integral factor of personal development, created by the school system, including didactic materials, organization of educational process, lessons, educational events, medical aid, nutrition, psychological climate in order to provide favorable conditions for harmonious development of a child, his/her abilities and interests.

We analysed a foreign studies' terminological apparatus on the problem of organization of a gender-equitable environment in the context of gender studies. First of all, the attention of the world's humanities is paid on a sphere of child's rights and freedoms observance and the introduction of nondiscriminatory and inclusive education to the school environment ("Gender Equitable Learning Environment", "Gender-balanced Education", "Gender equality in education", "Gender-equitable education", "Gender-fair Education", "Non-discrimination Education", «Non-sexist Education", "Human Rights Friendly School").

One of the important practice in the context of the organization of a gender-equitable environment at the educational institutions is the Human Rights Friendly School - HRFS (Amnesty International's global human rights education project for schools) and Child Friendly School (C. Wright, C. Mannathoko, M. Pasic) which aimed to make human rights an integral part of everyday school life. the school becomes an exemplary model for human rights education from the way how decisions are made in schools, the way how people communicate with each other, the curriculum and extra-curricular activities on offer, right down to the very surroundings in which students are taught. The HRFS is founded on equality, dignity, respect, non-discrimination and participation basis. It is a school community where human rights are learned, taught, practiced, respected, protected and promoted. The HRFS are inclusive environments where all are encouraged to take an active part in school life, regardless of status or role, and where cultural diversity is celebrated. Children can learn about human rights by putting into practice every day. Through an approach which goes beyond the classroom and into all aspects of school life, commonly called a "whole-school approach", a "holistic approach" or "rights-based approach", both schools and young people become powerful catalysts for change in their wider communities [18;21].

There are 4 groups of global principles of the HRFS:

1) Inclusion and Non-discrimination: (the community where equality, non-discrimination, dignity, and respect support all aspects of school life; provides a learning environment where all human rights are respected, protected and promoted; embraces inclusion in all aspects of school life);

2) Participation (encourages all members of the school community to participate freely, actively and meaningfully in school life; ensures that everyone in the school community has the information and resources they need to participate fully in school life);

3) Accountability (fair, accountable and transparent in its planning, processes, including decision making, policies, and practices; protects all members of the school community by making safety and security by a shared priority and responsibility);

4) Empowerment (through learning and teaching) (integrates human rights into all aspects of teaching and the curriculum; works to empower all students, without discrimination, to reach their full potential and capabilities through education; empowers students and staff to become active members of a global community, sharing knowledge, understanding and learning with others and taking action to create a world where human rights are respected, protected and promoted) [18, p. 5].

In the context of our study, we pay attention to the principles which are relevant to a rightsbased approach, in particular, equality and non-discrimination which means that all individuals are equal as human beings, and by virtue of the inherent dignity of each person, are entitled to their rights without discrimination of any kind. A rights-based approach requires a particular focus on addressing discrimination and inequality. Safeguards need to be included as development instruments to protect the rights and well-being of marginalized groups. As far as possible, data need to be disaggregated for example, by sex, religion, ethnicity, language, and disability - in order to give visibility to potentially vulnerable populations $[14$, p. 10].

Non-discrimination policy requires the introduction of a gender perspective at all levels, and includes: a) Teachers who receive adequate education and on-going in-service training throughout 
their career; b) School leadership receives support and resources needed to implement policy and is held accountable; c) Curricula are appropriate, regularly evaluated and updated accordingly; d) School resources are sufficient and in line with the needs of both female and male students; e) Prevention and remedies against corruption integrate a gender perspective and are in place at all levels of the education system; i) Schools are child-friendly and safe from all forms of violence and harassment; f) Community and families receive information and learn about the policies and rules affecting children's education. They are encouraged to contribute to discussions on school policies, rules, etc. through appropriate participation mechanisms [16, p. 2].

Scientists J. Larkin \& P. Staton (Canada) explain gender equality in education as a combination of important components: equal access, inclusiveness, friendly "climate" of educational environment and relationship between all participants of the educational process (girls, boys, teachers and parents). Equal access means the providing of equal opportunities for girls and boys to education; involvement of children to "non-stereotyped" spheres of activity; and widening the perceptions of children and youth about their future professional opportunities. They emphasize on taking account a factor of inclusiveness (which means gender, race, class, ethnicity, disability, etc.) in the organization of educational process: educational content, teaching forms and methods, communication of teaching staff with schoolchildren and colleagues (using a gender-sensitive language). This factor also means that teaching staff should react to sexism, racism and other forms of discrimination. J. Larkin interprets the principle of inclusiveness as maximum involvement of students of different social groups to providing quality educational services and to promote the full development of their potential. Otherwise, students may be in an unfavorable position which is caused by their gender, race, class, religion, language, disability, etc. In this context, the development of gender sensitivity and tolerance, mutual respect and understanding between student youth in the conditions of multiculturalism and diversity of Canadian society is an essential need [19, p. 361-376].

A gender-education environment in German school is organized on the basis of a Gender Equality Strategy adopted by the Government. Its implementation is ensured through: gender mainstreaming, gender and information space; gender statistics; wide-ranging educational campaigns on gender and social responsibility issues; development of gender competence of parents and teachers as factors of forming the gender culture of the young generation [20].

The key aspect of the methodology of organization of a gender-equitable environment is " $3 \mathrm{R}$ " method (representation, resources, realia) by G. Ostrem (Sweden) and a set of active social and psychological methods of teaching (gender training, case study, narrative, etc.), conducting of antidiscrimination expertise of educational content, teaching system, and gender audit of educational institutions.

Thus, for the providing equitable and non-discriminatory education, governments must: a) ensure the principles of equity and non-discrimination are enshrined in national legislation and cover administrative practices as well as the individual acts of public authorities; $b$ ) ensure that social inclusion is promoted and mainstreamed throughout the education system, including financing, policy development, curriculum, and pedagogical practice, as well as teacher training; c) ensure that measures for increasing access to education, reducing drop-out rates and improving retention and completion rates identify and target communities that are most marginalized [15, p. 1].

Generalization of foreign experience and the best educational practices in the context of this research gives the opportunity to form our own vision as to further institutionalization of gender to educational space, in particular, organization of a gender-equitable environment in the condition of reforming the national school $[5 ; 12]$. According to the President of the National Academy of Pedagogical Sciences of Ukraine V. Kremen: "All educational activity and system of relations in society, the attitude of adults to children should be based on the principles of innovation and childcenterism" [6, p. 412].

We interpret a gender-equitable environment as creative-developing, health-saving, nondiscriminatory and inclusive environment for children (taking into account their gender, age, disability, ethnicity, race, etc.), which are relevant to the principles of social justice, gender equality, child-centrism, egalitarianism, non-discriminatory education, and "partnership pedagogy", gender "matrix" of humanistic pedagogical heritage; in the conditions of which the full development of personality is ensured [5, p. 17]. It is a safe place for students, relevant their developmental needs in a social and cultural context; based on the subject-subjective approach and pedagogy of partnership; 
promoting the development of children's live creativeness and friendships, respect for peers and teachers; forming an independent and responsible person [10, p. 44-55].

Structure of a gender-equitable environment include three components: spatial-objective (location of the institution, interior and exterior, availability of recreation areas, background, on which the relations between all participants of the educational process is happening; psychodidactic - content sphere (curriculum and plans, textbooks, manuals, forms, methods and techniques of teaching and education, which are conditioned by the psychological goals of the creating an educational process); social - subjects of educational process (teachers, parents, students); communication sphere: the style of interaction between teachers, students and parents [5, p. 17].

The analysis of scientific literature show that the organization of an educational environment in Ukrainian school is stereotyped and is represented in the content of its components. In particular, the spatial-objective component is determined by the "female" and "male" territories, separate cabinets of labour training for girls and boys, dressing rooms, etc.; the algorithm of forming at physical classes, when the first in the rank are boys, and girls are after them. It is the informal mechanism of gender segregation, which de-jure is not noted in any normative document, but de-facto exists. Researchers have found that space, which is occupied by boys (sports grounds, corridors), is much larger than the "girl's territory" (class, toilet, some part of the corridor and schoolyard), percentage relation is $70,0 \%: 30,0 \%$ respectively. Children spend their free time at breaks and after classes here $[1 ; 8 ; 9]$. At primary school, we can see individual game zones with different equipment for games for girls and boys. These are dolls, books, elastic band for girls and machines, constructors, desktop intellectual games for boys.

Another aspect of the spatial-subject component deals with "wall space" (information stands, posters, ads, etc.). O. Marushchenko and O. Plakhotnik have noted that if you pay attention to the poster "Pride of the school", you can see that the photos of girls-excellent are more than boysexcellent (about 1,5-2 times). The research results have been shown that the girls' success in the studies is higher, but it isn't due to their innate inclination for study, but stereotyped upbringing when they are brought up attentive, diligent, persistent, and disciplined. In this case, girls conform to school requirements easier. It affirms about gender-differential education, instead personally oriented approach, which can ensure necessary conditions for maximum self-realization and development of girls' and boys' abilities. Boys are also often depicted on the posters "Safety on a road", "Caution, Fire!", "Take care of your safety!" as disturbers or heroes, who save other people' lives. It is an indication of discriminatory education and the existence of a stereotype that boys more often demonstrate risky and dangerous behavior, while passive girls "do everything right" $[8 ; 9 ; 10]$.

The psychodidactic component of a gender-equitable environment includes the State Standard of Primary and Secondary education, curriculum, textbooks, and manuals. This component is shown in the context of conducted anti-discrimination (gender) expertise which aims to reveal discrimination in the text and non-textual materials of educational content (textbooks, manuals, and other didactic materials) taking into account different peculiarities, protected by the Constitution of Ukraine (race, color, political, religious and other convictions, gender, age, disability, ethnicity and social origin, language, etc.) which causing xenophobia, ageism, andro- and ethnocentrism, sexism, etc.; and provide recommendations for their avoidance [3, p. 6-21]. The main method of such expertize is content analysis. We conducted gender expertize of educational materials for primary school. The conclusion: de jure relevance of educational materials of primary school to the principles of gender equality was shown. De facto the elements of hidden discrimination uncovered: in pedagogical interaction in system teacher-schoolboys/schoolgirls; traditional sex-role requirements to studying and behaviour of students; an ambivalence of stereotyped and egalitarian teacher's attitudes; genderstereotyped textbooks 'Basics of Health' for 1-4 classes; an imbalance of gender representatives of both sexes; a marking of male sex [2; 17].

The basis for the organization of a gender-equitable environment is the correlation and interdependence between social pedagogical and psychological processes on the social and individual levels of gender self-determination of children and youth, in patriarchal and egalitarian coordinates. The principles of gender education are: science, an objectivity of gender knowledge as the main ground for deprivation of stereotypes, its adequacy for normal developing by children's age possibilities, teenagers and youth; positivism and tolerance in attitudes to both sexes and interpersonal communication; conducting personality's experience, critical comprehension of the formed 
instructions as to life as man or woman; subjective position as a condition of gender self-determination activation and self-reflection in educational dialogue; overcoming sexual stereotypes; equality of "male" and "female" in the content of didactic material, the refusal of the strategy of marginalization of women as less important [4, p. 9].

In the study we pay attention to "partnership pedagogy" and gender "matrix" of humanistic pedagogical heritage, integration of competent, personal oriented and gender approaches which help into formation of gender culture and the egalitarian outlook of children (gender competence, sensitivity and tolerance) as important factors of personal and professional self-realization of both sexes, democratic world-view and civilian girls' and boys' life-realization in the sphere of national being.

The famous Ukrainian pedagogue-humanist V. Sukhomlynskyi said: "The education of true men and true women begins with the formation of their civil personal qualities" [13, p. 556.]. These words are a guide in gender education of children.

A parity, mutual respect of both sexes has got its pedagogical filling in the works by another prominent educator - A. Makarenko in relation to the conditionality of social and family roles of men and women and connected with those valued orientations, importance of maternal and paternal influence on the development of sexual identification of a child: "Real love between parents, respect to each other, help and care, frankly possible displays of tenderness and kindness... serve as mighty educational factor, and surely, excite in children attentiveness to such serious and good mutual relations between a man and a woman" [7, p. 300].

In unison to the modern gender dialogue about upbringing of androgynous personality are S. Rusova' words: "Upbringing should develop a child's respect and experience of individual value, respect for the public view; enrich the child with his/her subjective creative powers, faith in the valuables of his/her thoughts, and also teach him/her to recognize and respect the views of other people" [11, p. 99].

Thus, the unique essence of "gender matrix" of the Ukrainian pedagogical legacy lies in the forming of the cultural oriented society for the development of modern gender education in the national school on the following principles: equality, dialogue, participation of adults and children in the organization of school life, providing equal opportunities for boys and girls; because it focuses on each child as a personality. Under these conditions, a model of psychological and pedagogical support of gender socialization of children and youth is proposed. It helps developing ideas about the partnership of both sexes, formation of gender-parity interaction between all subjects of the educational process, intensification of their self-determination in issues of gender culture.

Consequently, based on the foreign experience and methodological principles of the Ukrainian pedagogical heritage, the organization of a gender-equitable environment in Ukrainian school involves the creation of free space, without any form of discrimination, in the conditions of which the full development of the personality is ensured (taking into account gender, age, disability, nationality, race, etc.); in addition to non-discriminatory education and the principle of equality are realized.

The prospect of further studies concern to the experimental study of the content, structure and peculiarities of the functioning of the educational environment, the development of indicators and principles of non-discriminatory education.

\section{REFERENCES}

1. Гендерна педагогіка: навчальний посібник для студентів вищих навчальних закладів; за ред. В. Гайденко. - Суми: Університетська книга, 2006. - 314 с.

2. Гендерні стандарти сучасної освіти. Рекомендації щодо впровадження гендерних підходів у систему дошкільної та початкової освіти України: збірка рекомендацій / ред. рада О. М. Кікінежді, В. С. Власов, Л. Б. Магдюк, Т. В. Ладиченко. - К.: ПРООН, 2010. - Ч. 1. - С. 5-75.

3. Експертиза шкільних підручників: інструктивно-методичні матеріали для експертів щодо здійснення антидискримінаційної експертизи електронних версій проектів підручників, поданих на конкурсний відбір проектів підручників для 1 класу закладів загальної середньої освіти / за заг. ред. О. А. Малахової. - К.: Представництво Фонду ім. Гайнріха Бьолля в Україні, 2017. - 40 с.

4. Кравець В. П. Гендерна освіта: теорія та практика: навчальна програма з інтегрованого курсу для студентів педагогічних вузів / В. П. Кравець, Т. В. Говорун, О. М. Кікінежді // Гендерні стандарти сучасної освіти. Збірка рекомендацій. - Запоріжжя: Друкарський світ, 2011. - Ч. 3. - С. 9-72.

5. Кравець В. П. До проблеми гуманізації освітньо-виховного простору сучасної української школи / В. П. Кравець, О. М. Кікінежді, І. М. Шульга // Освітологія. - 2018. - № 7. - С. 15-21. 
6. Кремень В. Г. Філософія людиноцентризму в стратегіях освітнього простору / В. Г. Кремень. - К.: Педагогічна думка, 2008. - 424 с.

7. Макаренко А.С. Вибрані педагогічні твори. - К.: Рад. школа, 1950. - Т. 1. - 303 с.

8. Марущенко О. Гендерні шкільні історії / О. Марущенко, О. Плахотнік. - Х.арків Монограф, 2012. - 88 с.

9. Марценюк Т. Гендер для всіх. Виклик стереотипам / Т. Марценюк. - К.: Основи, 2017. - 256 с.

10. Нова українська школа: порадник для вчителя; за заг. ред. Н. М. Бібік. - К.: Літера ЛТД, 2018. $160 \mathrm{c}$.

11. Русова С. Вибрані педагогічні твори: у 2 кн. / С. Русова. - К.: Либідь, 1997. - Кн. 2. - 318 с.

12. Сисоєва С. О. Освітологічний контекст освітніх реформ / С. О. Сисоєва // Освітні реформи: місія, дійсність, рефлексія: монографія / за ред. В. Кременя, Т. Левовицького, В. Огнев’юка, С. Сисоєвої. - К.: ТОВ «Видавниче підприємство “ЕДЕЛЬВЕЙС”», 2013. - 460 с.

13. Сухомлинський В. О. Вибрані твори: в 5 томах / В. О. Сухомлинський. - К.: Рад. школа, 1977. T. $5 .-639$ c.

14. A Human Rights-Based Approach to EDUCATION FOR ALL. - New York-Paris, 2007. -161 p.

15. Equitable and Non-discriminatory Quality Education [Online version].- Access: https://eiie.org/media_gallery/Policybrief_07_equitable_eng.pdf.

16. Gender Equality in the Education Sector - Focusing on issues of quality of education and Completion [TOOL]. Gender Equality in the Education Sector (Sida). Stockholm, 2017. - June. - 4 p.

17. Gender, politics, and society in Ukraine / Eds. O. Hankivsky, A. Salnykova. - Toronto: University of Toronto Press. 2012. - 44 p.

18. Human Rights Friendly Schools: TOOLKIT (Amnesty International). - London: Peter Benenson House, 2017. -44 p.

19. Larkin J. Access, Inclusion, Climate, Empowerment (AICE): A Framework for Gender Equity in MarketDriven Education / J. Larkin, P. Staton // Canadian Journal of Education. - 2001. - Vol. 26. - No. 3. P. 361-376.

20. Rose L. Gender Mainstreaming in der Kinder und Jugendarbeit / L. Rose. - Juventa; Beltz; Votum, 2004. $-124 \mathrm{~s}$.

21. Wright C. Child friendly school: manual / C. Wright, C. Mannathoko, M. Pasic. - New York: UNICEF's Division of Communication. - 2009. - 244 p.

\section{REFERENCES}

1. Genderna pedahohika: navchalnii posibnyk / za red. V. Gajdenko [Gender pedagogy: tutorial]. Sumy: Universytetska knyga, 2006. 314 p.

2. Genderni standarty suchasnoi osvity. Rekomendacii shhodo vprovadzhennia gendernykh pidxodiv u systemu doshkilnoi ta pochatkovoi osvity Ukrainy: zbirka rekomendacii / red. rada O. M. Kikinezhdi, V.S. Vlasov, L. B. Magdiuk, T. V. Ladychenko [Gender Standards of Modern Education. Recommendations on the implementation of gender approaches into the system of preschool and primary education of Ukraine: a collection of recommendations]. Kyiv: PROON, 2010. Part 1. PP. 5-75.

3. Ekspertyza shkilnykh pidruchnykiv: instruktyvno-metodychni materialy dlia ekspertiv shhodo zdijsnennia antydyskryminacijnoyi ekspertyzy elektronnykh versii proektiv pidruchnykiv, podanykh na konkursnyi vidbir proektiv pidruchnykiv dlia 1 klasu zakladiv zagalnoi serednoi osvity / za zag. red. O. A. Malaxovoyi [Expertize of school textbooks: guidance materials for experts on the implementation of antidiscrimination expertise of electronic versions of textbooks projects submitted for competitive selection of textbooks for 1 grade of institutions of general secondary education]. Kyiv: Predstavnycztvo Fondu im. Gajnrixa Bollya v Ukraini, 2017. - 40 p.

4. Kravets V. P., Govorun T. V., Kikinezhdi O. M. Genderna osvita: teoriia ta praktyka: navchalna programa $\mathrm{z}$ integrovanoho kursu dlia studentiv pedagogichnykh vuziv [Gender education: theory and practice: integrated curriculum for students of pedagogical universities]. Genderni standarty suchasnoyi osvity. Zbirka rekomendacij. Zaporizhia: Drukarskii svit, 2011. Par. 3. PP. 9-72.

5. Kravets V. P., Kikinezhdi O. M., Shulga I. M. Do problemy gumanizacii osvitno-vyxovnoho prostoru suchasnoi ukrayinskoi shkoly [To the problem of huanization of educational space of modern Ukrainian school]. Osvitologia. 2018. Vol. 7. PP. 15-21.

6. Kremen V. G. Filosofia liudynocentryzmu v strategiakh osvitnoho prostoru [Philosophy of humancentrism in the strategies of educational space]. Kyiv: Pedahohichna dumka, 2008. 424 p.

7. Makarenko A. S. Vybrani pedagogichni tvory [Selected pedagogical works]. Kyix: Rad. shkola, 1950. T. $1.303 \mathrm{p}$.

8. Marushhenko O., Plaxotnik O. Genderni shkilni istorii [Gender school stories]. Kharkiv: Monograf, 2012. $88 \mathrm{p}$.

9. Marceniuk T. Gender dlia vsikh. Vyklyk stereotypam [Gender for everyone. Challenge for stereotypes]. Kyiv: Osnovy, 2017. - 256 p. 
10. Nova ukrainska shkola: poradnyk dlia vchytelia / za zag. red. N. M. Bibik [New Ukrainian School: teacher's guide]. Kyiv: Litera LTD, 2018. $-160 \mathrm{p}$.

11. Rusova S. Vybrani pedahohichni tvory: u 2 kn. [Selected pedagogical works: in 2 books]. Kyiv: Lybid, 1997. Book. 2. 318 p.

12. Sysoieva S. O. Osvitologichnyi kontekst osvitnikh reform / S. O. Sysoieva [Educational context of educational reforms] // Osvitni reformy: misia, dialnist, refleksia: monografia / za red. V. Kremenia, T. Levovyczkoho, V. Ogneviuka, S. Sysoievoi. - Kyiv: TOV «Vydavnyche pidpryiemstvo "EDELVEJS"», 2013. $460 \mathrm{p}$.

13. Sukhomlynskyi V. O. Vybrani tvory: $\mathrm{v} 5$ tomakh [Selected work: in 5 volumes]. Kyiv: Rad. shkola, 1977. Vol. 5. $639 \mathrm{p}$.

14. A Human Rights-Based Approach to EDUCATION FOR ALL. New York-Paris, 2007. $161 \mathrm{p}$.

15. Equitable and Non-discriminatory Quality Education. [Online version]. - Access: https://eiie.org/media_gallery/Policybrief_07_equitable_eng.pdf.

16. Gender Equality in the Education Sector - Focusing on issues of quality of education and Completion [TOOL]. Gender Equality in the Education Sector (Sida). Stockholm, 2017. June. 4 p.

17. Gender, politic, and society in Ukraine / Eds. O. Hankivsky, A. Salnykova. Toronto: University of Toronto Press. 2012. 44 p.

18. Human Rights Friendly Schools: TOOLKIT (Amnesty International). London: Peter Benenson House, 2017. $44 \mathrm{p}$.

19. Larkin J. Access, Inclusion, Climate, Empowerment (AICE): A Framework for Gender Equity in MarketDriven Education / J. Larkin, P. Staton // Canadian Journal of Education. 2001. Vol. 26. No. 3. P. 361376.

20. Rose L. Gender Mainstreaming in der Kinder und Jugendarbeit/L. Rose. Juventa; Beltz; Votum, 2004. $124 \mathrm{~s}$.

21. Wright C. Child friendly school: manual / C. Wright, C. Mannathoko, M. Pasic. New York: UNICEF's Division of Communication. 2009. 244 p.

Стаття надійшла в редакиію 25.03.2019 р. 